\title{
Evaluation of Honey Producing Potential of Robinia pseudacacia in Reforested Old Lignite Mines in West Macedonia
}

Fotini Papadopoulou', Marina Tentsoglidou², Francis Pavloudakis ${ }^{2}$, Nikolaos Papadimopoulos ${ }^{2}$ and Ioannis Papadopoulos ${ }^{1}$

1. Technological Education Institute of West Macedonia, Florina 53100, Greece

2. Public Power Corporation S.A., West Macedonia Lignite Centre, Ptolemaida 50200, Greece

\begin{abstract}
Opencast mining is important for local and global economy, but this operation mostly and inevitably leads to substantial environmental damage. Potential future use of the post-mining lands basically depends on the nature of the land, soil conditions, and communal structure of nearby surrounding to be rehabilitated by technical, biological, agricultural means or forestry applications. Vegetation cover has significant functions on post-mining landscapes so, in order to reduce the probability of negative impacts, selection of suitable plant material, which may be preferably native but also introduced plant species, is critical. In West Macedonia Lignite Centre, about 1,500 ha of these land has already reforested by the Public Power Corporation S.A., with Robinia pseudacacia L., one of the most criticized non-native tree species in Europe, because its rootstocks spread into neighbouring areas, repressing native species. The tree is an excellent species for revegetating poor or damaged soils and its fast-growing nature, makes it popular for former lignite mine reclamation, reforestation and erosion control. Robinia forests represent a valuable nectar and pollen source in late spring for many insects, especially Hymenoptera, such as Apis mellifera. That has increased dramatically the regional honey producing potential. In this study, the annual potential honey production of 1,500 ha black locust forests established in reforested old mines land, was estimated from 50,000 to $70,000 \mathrm{~kg}$ honey, depending on the year, which is sufficient for up to1,000 bee hives to survive for one year. For the efficient utilization of this valuable honey producing source by the beekeepers, a plan should be developed, to facilitate accessibility to the region and proper beehives dispersion.
\end{abstract}

Key words: Robinia pseudacacia, lignite mine reclamation, reforestation, honey production.

\section{Introduction}

Coal mining forms an important industry branch, which covers a large segment of energy demand in Greece while coal mining entails infrastructure and jobs for West Macedonia region, and it has caused significant modifications in numerous environmental constituents of the greater area mainly due to their size and the applied surface mining method. Potential future use of the post-mining lands basically depends on the nature of the land, soil conditions, and communal structure of nearby surrounding to be

Corresponding author: Francis F. Pavloudakis, Ph.D. (Mineral Resources Eng.) \& MSc (Environmental Eng.), engineer, research fields: environmental management \& land reclamation of surface mines. rehabilitated by technical, biological, agricultural means or forestry applications.

In West Macedonia Lignite Centre, about 1,500 ha of old lignite mines land have already reforested by the Public Power Corporation S.A., with Robinia pseudacacia L., one of the most criticized non-native tree species in Europe, because its rootstocks spread into neighbouring areas, repressing native species [1].

Known as the black locust in the USA and as false acacia in Europe, Robinia pseudoacacia L. belongs to the Fabaceae family and has been imported all over Europe since the beginning of the eighteenth century thanks to its ability to adapt to different environmental conditions. The tree has nodules of nitrogen-fixing bacteria on its roots which makes it an excellent 
species for revegetating poor or damaged soils and its fast-growing, sun-light loving and unpretentious nature makes it popular for former brown-coal mine reclamation, reforestation and erosion control (Fig. 1).

In addition, black locust starts flowering early, often at an age of six years [2] and the flowers are highly valued for their source of nectar and pollen for many insects, especially Hymenoptera, such as Apis mellifera (Fig. 2). Black locust honey is often sold as acacia honey [3] and the production of this type of honey is very common and economically important [2].

The research objective of this study is to evaluate the honey producing potential of the largest black locust forest that can be found in Greece, created by
PPC (Public Power Corporation S.A.) plantations in West Macedonia Lignite Centre, by estimation of the number of flowers and nectar production of $R$. pseudoacacia.

\section{Experimental Setup}

The study area was previously used for brown-coal mining and has now been recultivated with different tree species. The black locust plantations started 30 years ago and continued up to 2016 covering more than 1,500 ha with average density 2,000 trees per ha. Plantations were classified in four categories depending on the tree age, planting density and canopy diameter (Table 1).

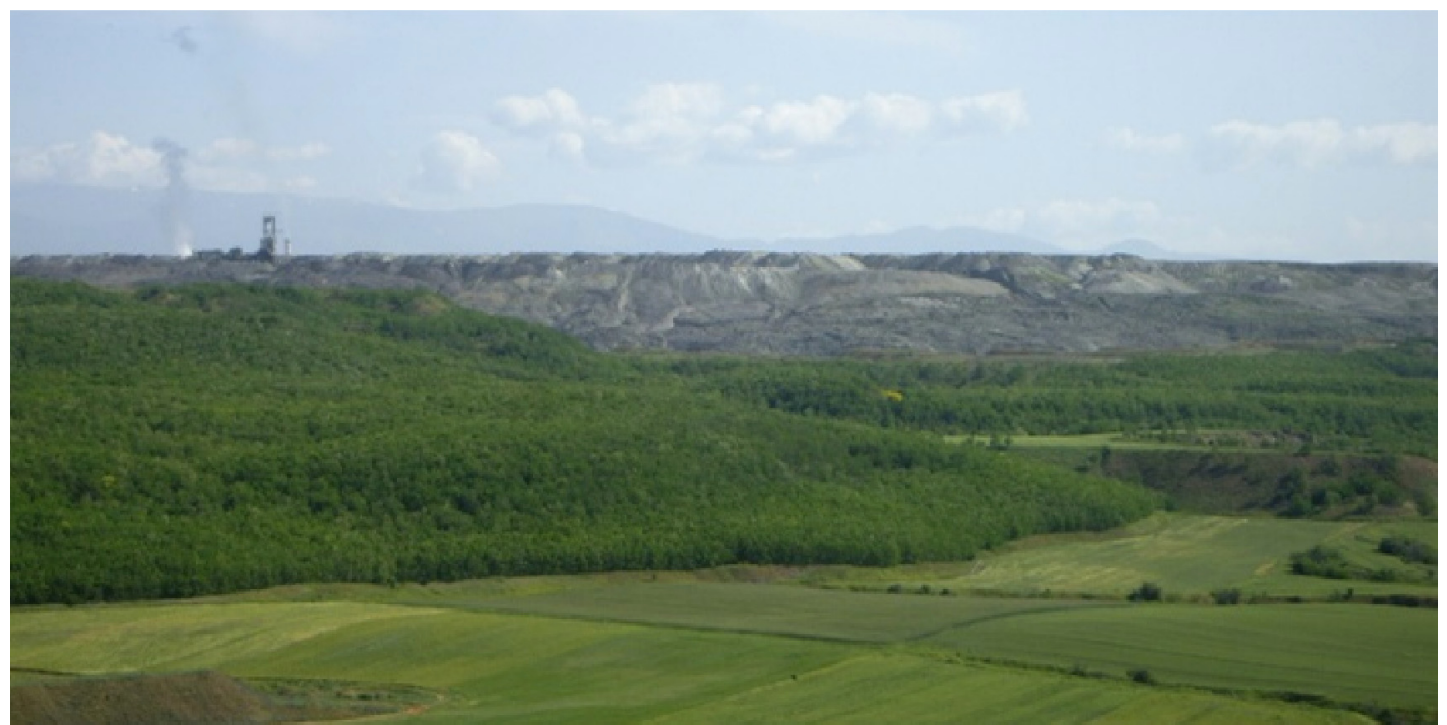

Fig. 1 Robinia pseudoacacia L. plantations used for slope stabilisation and erosion control in Amynteon mine, West Macedonia Lignite Centre, Greece.

Table 1 Area of Robinia forest categories according to the age and canopy cover percentage and estimated nectar production.

\begin{tabular}{llllll}
\hline & Robinia forest category & Area (ha) & $\begin{array}{l}\text { Mean number } \\
\text { flowers/ha (millions) }\end{array}$ & Nectar/ha* $(\mathrm{kg})$ & Nectar production (kg) \\
\hline A & $\begin{array}{l}\text { 10 years old, } \\
\text { canopy cover }>90 \%\end{array}$ & 874.5 & 10.24 & 112.6 & 98,500 \\
B & $\begin{array}{l}\text { 10 years old, } \\
\text { canopy cover } 70-90 \%\end{array}$ & 321.7 & 11.41 & 125.5 & 40,400 \\
C & $\begin{array}{l}\text { 10 years old, } \\
\text { canopy cover 50-70\% }\end{array}$ & 17.8 & 9.75 & 107.3 & 1,900 \\
D & $\begin{array}{l}\text { 6-10 years old, } \\
\text { canopy cover 70-90\% }\end{array}$ & 247.3 & 8.83 & 97.1 & 24,000 \\
E-10 years old, & $\begin{array}{l}\text { canopy cover 50-70\% } \\
\text { Total }\end{array}$ & 36.0 & 7.89 & 86.8 & 3,100 \\
\hline
\end{tabular}

* Assuming $2 \mathrm{mg}$ nectar yield/flower/day, and average flowering period of 5.5 days. 

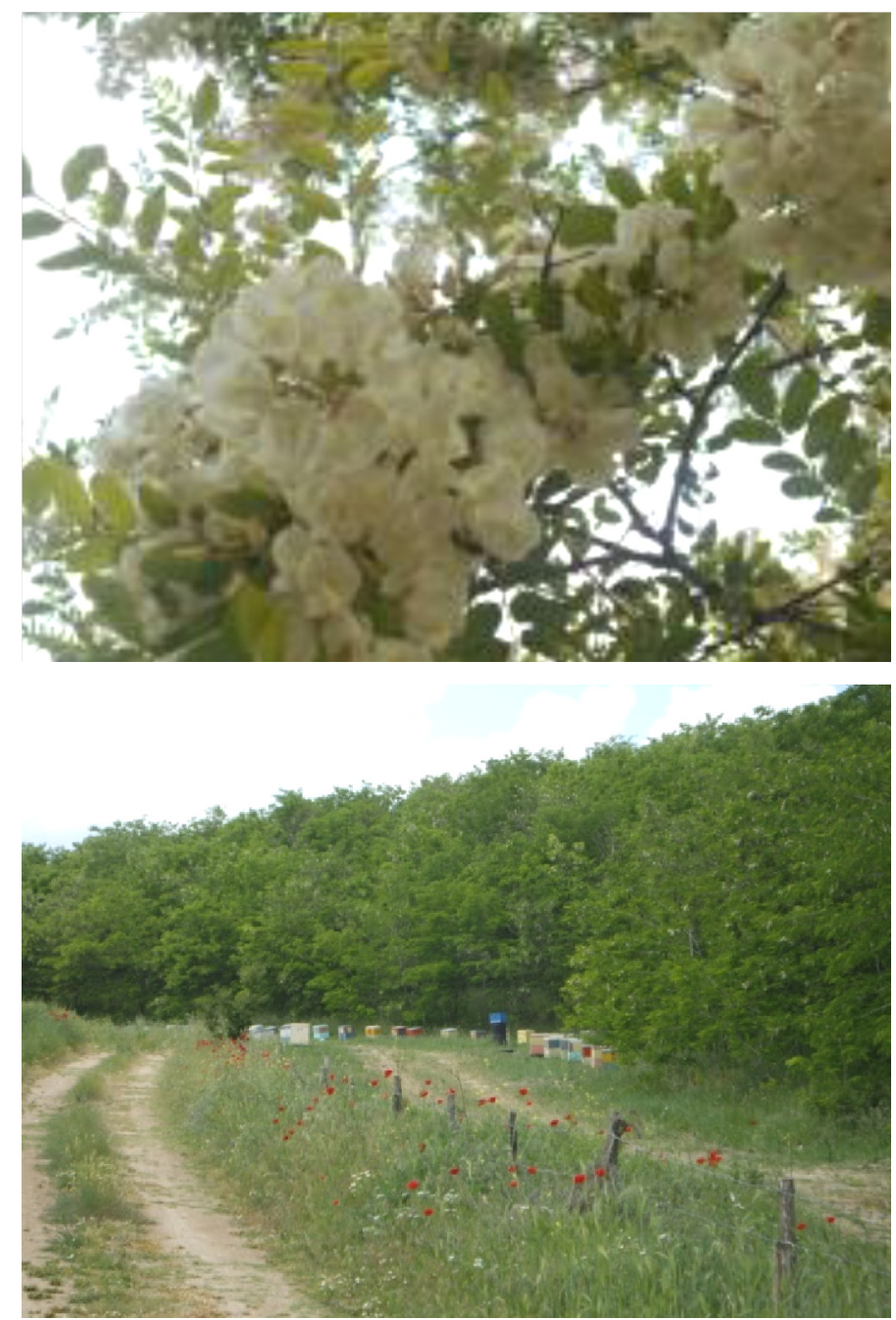

Fig. 2 (a) The flowers of Robinia pseudoacacia L.; (b) Bee hives located at the foot of the reclaimed waste heap of Amynteon mine.

For each category, three $100 \mathrm{~m}^{2}$ plots were selected randomly and all trees harvested at May 2015 flowering period and flowers weighted. Furthermore, a sample of 100 inflorescences of each plot were selected randomly, weighted and the total number of flowers was counted.

The total flower number for each plot is calculated:

No. of plot flowers $=$ total weight of flowers/(weight/number of sample flowers)

The mean flower number per hectare for each category is calculated by multiplying the mean flower number of the 3 plots by 100 .

Nectar estimation is based on literature information [4-6]. R. pseudoacacia blossoms flower for 5.5 days and produces 1.6-3.7 mg nectar per flower over $24 \mathrm{~h}$.
Robinias nectar has a sugar concentration of $34-67 \%$, so the sugar mass per flower over $24 \mathrm{~h}$ is $0.8-2 \mathrm{mg}$.

\section{Results}

Based on aerial photographs (Fig. 3), the total Robinia forests area is classified in five categories depending on the canopy cover percentage (Table 1).

Mean numbers of flowers/ha and corresponding nectar production/ha were higher in plantations with an age $>10$ years than younger plantations. Farkas and Zajacks [6] reported, nectar and honey yield of black locust in Hungary, increases from year 6 to year 15. Within the same age plantations those with lower canopy cover produced more flowers/ha compared to those with greater canopy cover. In Eucalyptus nitens 


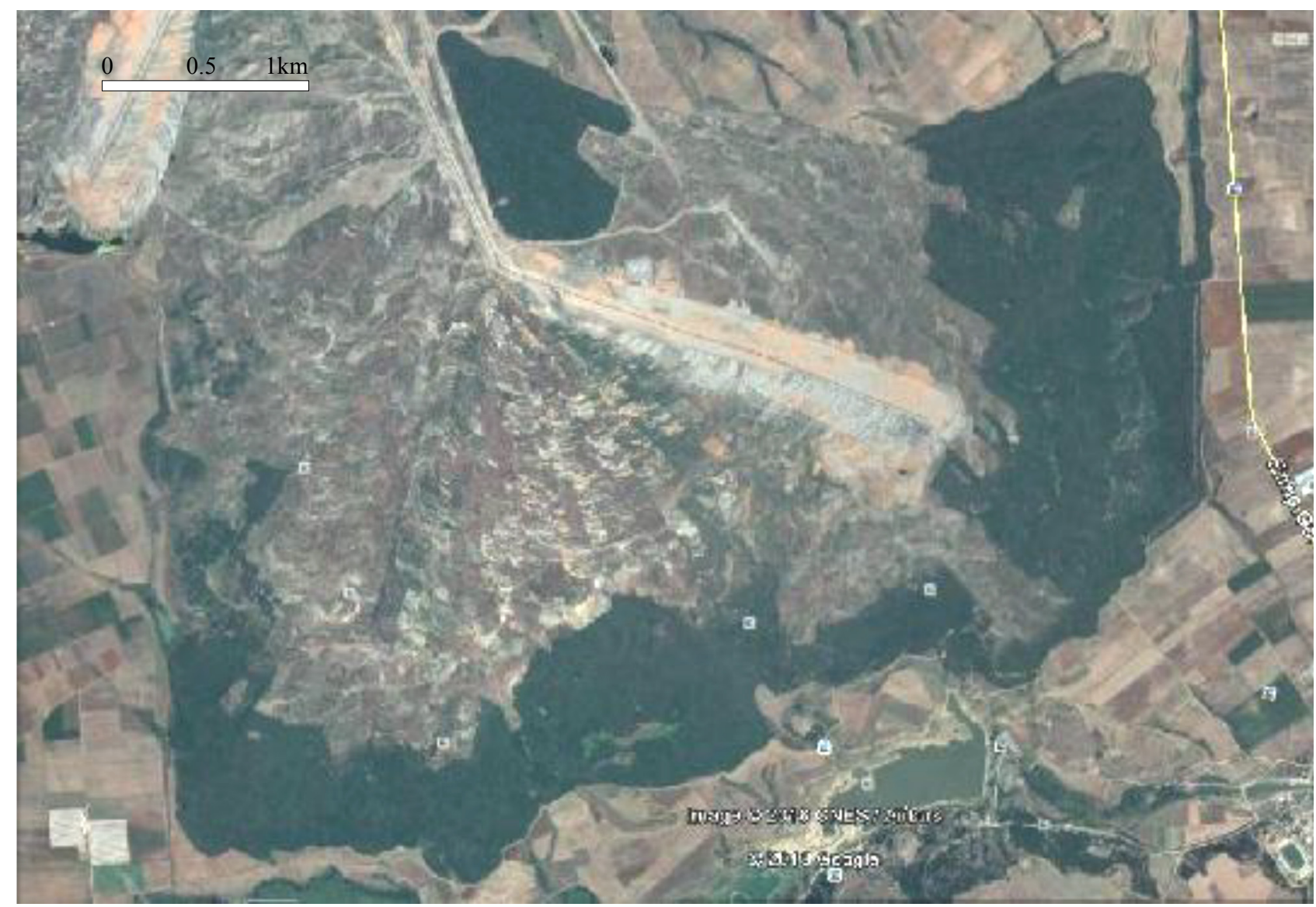

Fig. 3 Aerial photograph of Robinia pseudoacacia L. plantations (dark green colour) in the waste heap of Amynteon mine, West Macedonia Lignite Centre, Greece.

as tree density decreased, the production of flowers and capsules increased on both a per-tree and per-hectare basis [7].

Robinia flowers attract the honey bee as well as other bee species. Papilionate flowers, such as those of Robinia pseudoacacia L., show tripping mechanisms that prevent pollen release: only those bees which apply the right force on petals induce pollen to be deposited on their bodies. Apis mellifera is considered a poor visitor of such flowers, since individuals are usually too weak to trip the mechanism.

This deficiency has been acknowledged as the reason why honey bees usually avoid flowering Fabaceae [8], visit already tripped flowers [9] or turn to alternative strategies, such as robbery, to collect nectar on them $[10,11]$.

In the first day of anthesis, authors recorded many visits of Xylocopa sp. and Bombus sp. on Robinia flowers but none of Apis melifera honeybees.

In fact, Apis mellifera cannot access nectar in Robinia flowers at the beginning of anthesis with petals perfectly distended and fresh, therefore the main collection starts when flowers show the first evidence of ageing. Ageing flowers may differ from the arrangement [12] and turgescence of their petals due to water loss during flowering or due to previous visits of other pollinators. Authors estimate $70-90 \%$ of the total nectar secretion of Robinia flowers can be utilized by $A$. mellifera colonies. That means $50-70 \mathrm{t}$ of honey/year is obtainable in Robinia forests of Lignite Center in West Macedonia which is sufficient for up to1,000 bee hives to survive for one year. Nectar flows vary from year to year as are very dependent on local weather conditions. Good forage activity cannot be expected under $20{ }^{\circ} \mathrm{C}$. Heavy rains, which are often the case at the flowering of the black 
locust enhance the aging and destruction of flowers and thus can cause severe losses exceeding $50 \%$ of the expected nectar flow.

Robinia honey, is the latest crystallizing among honeys, has a mild flavour, has an important role in the international honey market, considering both quantity and quality. Among European countries, producing significant amount of Robinia honey are Hungary, Romania, Italy, France and Slovakia. Since a prerequisite of producing Robinia honey is the effective positioning of beehives in order for the colonies to be maximally able to collect the nectar, a plan should be developed, to facilitate accessibility to the Lignite Centre of West Macedonia R. pseudoacacia plantations and proper beehives dispersion.

\section{Conclusion}

Opencast mining is important for global economy and regional development. However, this operation threatens quality of environmental in numerous ways. Particularly in cases of large-scale coal and lignite mines, the disturbance of land is an unavoidable impact that affects both nature and society. Therefore, the development of a site-specific land reclamation programme is essential for minimizing the adverse environmental impacts. To this extent, the establishment of a vegetation cover has significant functions on post-mining landscapes. This is also the case of West Macedonia Lignite Centre, where about of 1,500 ha of waste heaps final surfaces have already reforested with Robinia pseudacacia L.. This is one of the most criticized non-native tree species in Europe, because its rootstocks spread into neighbouring areas, repressing native species. Nevertheless, this tree is an excellent species for revegetating poor or damaged soils and its fast-growing nature, makes it popular for former lignite mine reclamation, reforestation and erosion control.

Robinia forests represent a valuable nectar and pollen source in late spring for many insects, especially Hymenoptera, such as Apis mellifera. That has increased dramatically the regional honey producing potential. In this study, the annual potential honey production of 1,500 ha black locust forests established in reforested old mines land, was estimated from 50,000 to $70,000 \mathrm{~kg}$ honey, depending on the year, which is sufficient for up to 1,000 bee hives to survive for one year.

Taking into consideration the above facts, the efficient utilization of this valuable honey producing source must be taken into account in decision-making and planning procedures related to the selection of the optimum mix of land uses for the reclaimed mine land.

\section{References}

[1] Basnou, C. 2016. Delivering Alien Invasive Species Inventories for Europe-Species Factsheet Robinia Pseudoacacia. European Commission under the Sixth Framework Programme through the DAISIE Project. Available online: http://www.europe-aliens.org/speciesFactsheet.do?specie sId $=11942$.

[2] Ridei, K. 2015. Black Locust (Robinia pseudoacacia L.) Growing in Hungary. Sarvar, Hungary: Hungarian Forest Research Institute, 72-3.

[3] Aronne, G., Buonanno, M., and De Micco, V. 2008. Improving honey production and marketing, edited by $\mathrm{S}$. B. R, Naples. ISBN 88-901941-3-8.

[4] Maurizio, A., and Graf1, I. 1982. Das Trachtpflanzenbuch. Nektar und Pollen-die wichtigsten Nahrungsquellen der Honigbiene (3rd ed.) Munich, German Federal Republic: Ehrenwirth Verlag.

[5] Cran, E., and Walker, P. 1985. "Some Nectar Characteristics of Certain Important World Honey Sources.” Pszczel. Zesz. nauk. 29: 29-45.

[6] Farkas, A., and Zajacz, E. 2007. "Nectar Production for the Hungarian Honey Industry." The European Journal of Plant Science and Biotechnology 1 (2): 125-51.

[7] Dean, R. W., Potts, B. M., Neilsen, W. A., and Joyce, K. R. 2013. "The Effect of Tree Spacing on the Production of Flowers in Eucalyptus nitens." Australian Forestry 69 (4): 299-304, doi: 10.1080/00049158.2006.10676250.

[8] Cordoba, S. A., and Cocucci, A. A. 2011. "Flower Power: Its Association with Bee Power and Floral Functional Morphology in Papilionate Legumes." Ann. Bot. 108: 919-31. doi:10.1093/aob/mcr196.

[9] Parker, I. M., Engel. A., Haubensak. K. A., and Goodell, K. 2002. "Pollination of Cytisus scoparius (Fabaceae) and Genista monspessulana (Fabaceae), Two Invasive 
Reforested Old Lignite Mines in West Macedonia

Shrubs in California." Madroño 49 (1): 25-32.

[10] Etcheverry, A. V., Aleman, M. M., and Figueroa Fleming, T. 2008. "Flower Morphology, Pollination Biology and Mating System of the Complex Flower of Vigna caracalla (Fabaceae: Papilionoideae)." Ann. Bot. 102: 305-16. doi:10.1093/aob/men106.

[11] Aronne, G., Giovanetti, M., and De Micco, V. 2012.
"Morphofunctional Traits and Pollination Mechanisms of Coronilla emerus L. Flowers (Fabaceae)." Scientific World Journal 1:381575, 8p.

[12] Willmer, P., Stanley, D. A., Steijven, K., Matthews, I. M., and Nuttman, C. V. 2009. "Bidirectional Flower Color and Shape Changes Allow a Second Opportunity for Pollination." Curr. Biol. 19: 919-23. 